Ilmenau University of Technology

Institute of Economics

Ilmenau Economics Discussion Papers, Vol. 19, No. 84

Competitive Balance and Attention Level Effects: Theoretical Considerations and Preliminary Evidence

Tim Pawlowski, Oliver Budzinski

März 2014

Institute of Economics

Ehrenbergstraße 29

Ernst-Abbe-Zentrum

D-98 684 Ilmenau

Phone 03677/69-4030/-4032

Fax 03677/69-4203

http://www.wirtschaft.tu-ilmenau.de

ISSN 0949-3859 


\title{
Competitive Balance and Attention Level Effects: Theoretical Con- siderations and Preliminary Evidence
}

\author{
Tim Pawlowski ${ }^{*}$, Oliver Budzinski ${ }^{\#}$ \\ *** This paper will be published in: O. Budzinski \& A. Feddersen (eds.), Contempo- \\ rary Research in Sports Economics - Proceedings of the $5^{\text {th }}$ ESEA Conference, Frank- \\ furt a.M. Lang, May/June 2014 ***
}

\begin{abstract}
We try to better understand possible reasons for deviations between statistically-measured competitive balance (CB) and perceived CB. Moreover, we suggest answers to the following questions: are there specific dimensions of $C B$ that are perceived to be significantly less balanced in the Danish Superligaen compared to the other two leagues? Are there objective measures that "confirm" the fans' perception or does OCB in general deviate from PCB?
\end{abstract}

Keywords: competitive balance, sports economics, behavioural economics, midterm outcome uncertainty, fan perception

\section{Introduction}

Following the uncertainty of outcome hypothesis $(\mathrm{UOH})$ introduced by Rottenberg with his seminal work in 1956, competitive balance (CB) represents an important element of attractiveness of professional sports leagues. However, many studies correlating measures of competitive balance and success indicators such as attendance or viewer figures have not been successful in establishing clear evidence for the relevance of $\mathrm{UOH}$ in European professional football.

For instance, studies using the Theil (1967)-measure to analyse the impact of shortterm (game) uncertainty on stadium attendance either found a non-significant (Benz, Brandes \& Franck 2009) or negative (Buraimo \& Simmons 2008) effect suggesting that some caution is required in the use of the $\mathrm{UOH}$ (Szymanski 2006). For instance, the negative effect may be explained with fans preferring to see either a favourite home team with the chance to win by clear margin (Forrest et al. 2005; Coates \& Humphreys 2010) or a favourite away team which offers the chance to see an upset (Coates, Humphreys \& Zhou 2014) or a strong brand with star players (Pawlowski \& Anders 2012). Also, in the longer run there is not much support for the $\mathrm{UOH}$. For instance, season-aggregate attendance has actually increased in some leagues (e.g.

Professor of Sports Economics, Sports Management \& Sports Media Research, Institute of Sports Sciences, University of Tübingen, Wilhelmstraße 124, D-72074 Tübingen, Email: tim.pawlowski@uni-tuebingen.de. The author gratefully acknowledges the financial support provided by an UEFA Research Grant.

* Professor of Economic Theory, Institute of Economics, Ilmenau University of Technology, Ehrenbergstraße 29, D-98698 IImenau, Email: oliver.budzinski@tu-ilmenau.de. The authors thank Ina Fredersdorf and Nadine Neute for valuable editorial assistance. 
Germany and England), even as European leagues have become increasingly dominated by a small number of teams over the last decade (Flores, Forrest \& Tena 2010; Pawlowski, Breuer \& Hovemann 2010; Pawlowski 2013b: 2). This motivated further research into a completely new direction, which Zimbalist (2002: 112) already suggested in 2002 by stating, that "the best measure of competitive balance is the one to which fans show the greatest sensitivity". Pawlowski (2013a; b) as well as Pawlowski \& Budzinski (2013) further developed this thought and measured the perception of competitive balance through the eyes of the fans by applying a stated preference approach. They found that the perceived competitive balance (PCB) indeed matters for fans.

However, an interesting puzzle occurs in their analysis as long-term PCB differs from long-term objectively measurable CB (OCB). Specifically, while the Danish Superligaen is perceived by the fans as being less balanced compared to the German Bundesliga and the Dutch Eredivisie, objective measures such as the competitive balance ratio (Humphreys 2002) suggest, that the Danish Superligaen is evenly or even more balanced than the other two leagues.

In this chapter, we try to better understand possible reasons for this gap between $\mathrm{OCB}$ and $\mathrm{PCB}$. Moreover, we try to find answers to the following questions: are there specific dimensions of $C B$ that are perceived to be significantly less balanced in the Danish Superligaen compared to the other two leagues? Are there objective measures that "confirm" the fans' perception or does OCB in general deviate from $\mathrm{PCB}$ ?

The remainder of this chapter is organised as follows: First, we recapitulate the findings of our previous studies to demonstrate the arising puzzle (chapter 2). We then discuss possible (theoretical) reasons for this puzzle (chapter 3 ) as well as some new supportive evidence for attention level effects, i.e. fans' perception may just focus on specific parts of the (and not the overall) league competition (chapter 4). Finally, a summary and some conclusions for further research are provided (chapter 5).

\section{Objective versus Perceived Competitive Balance: A Comparison}

With the objective to better understand the fans' view on competitive balance, a written survey was distributed amongst soccer fans in three countries in a recent research project. Overall, $n=1,203$ fans in Germany; $n=267$ fans in Denmark, and $\mathrm{n}=219$ fans in the Netherlands were surveyed in the stadiums and in bars where football matches are regularly broadcast live before/during 14 matches in the first divisions of the respective leagues. ${ }^{1}$

An index of overall PCB was measured with to different approaches: First, it was asked:

For a detailed description of the research project and the employed methods please refer to Pawlowski (2013a; 2013b) as well as Pawlowski \& Budzinski (2013). 
Thinking back to previous seasons: how would you rate the level of suspense/excitement ('Spannung') of the LEAGUE on a scale of $0-10$ ( $0 \equiv$ not at all suspenseful/exciting ... 10 三 very suspenseful/exciting)? ${ }^{2}$

Second, a (potentially oversimplified) scenario was tested to investigate the willingness-to-pay (WTP) of fans for CB:

Imagine you could increase the level of suspense/excitement ('Spannung') in the LEAGUE by making a financial contribution! How much would you be willing to pay per stadium ticket per game?

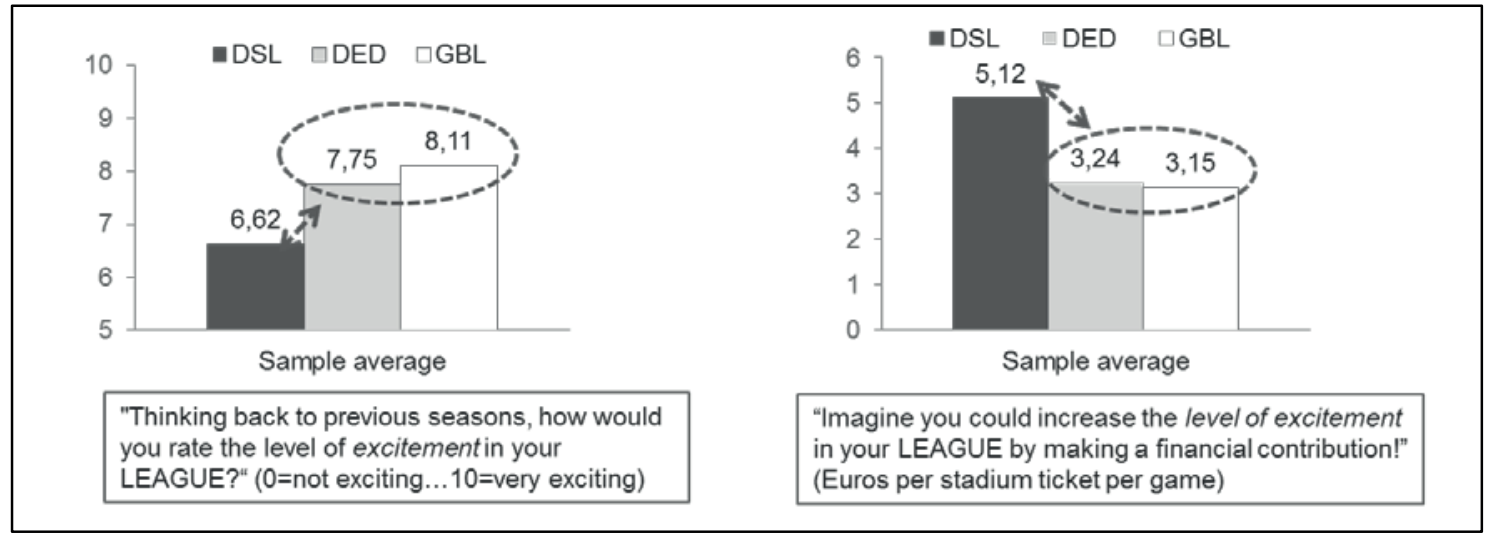

Figure 1: Perceived level of excitement and willingness-to-pay to increase the current level of excitement in the Danish Superligaen (DSL), the Dutch Eredivisie (DED) and the German Bundesliga (GBL) (Pawlowski 2013a).

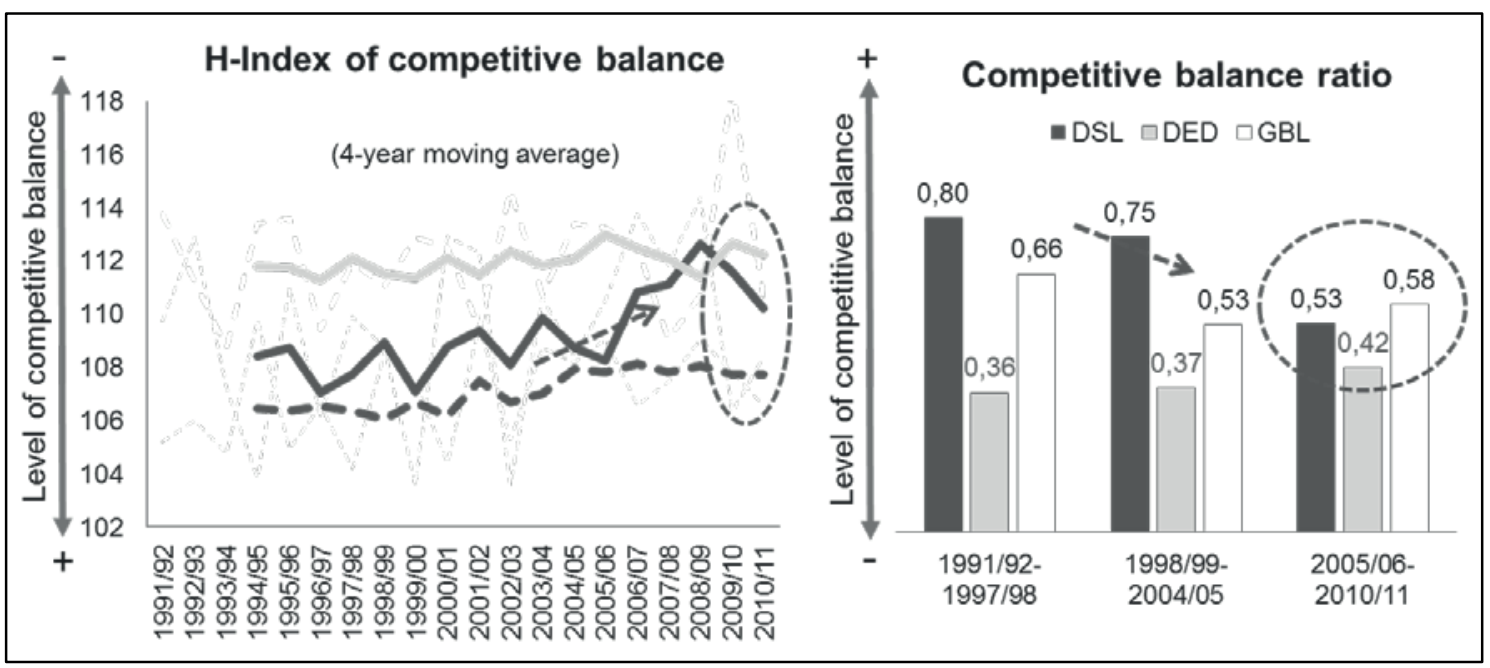

Figure 2: Trends in competitive balance in the Danish Superligaen (DSL), the Dutch Eredivisie (DED) and the German Bundesliga (GBL) (Pawlowski 2013a).

2 As various regression and principal component analysis reveal (Pawlowski 2013a; 2013b) the overall index of PCB generated this way (is partly explained by and therefore) reflects the short-, midand long-term dimensions of CB as proposed in the literature (Cairns, Jennett \& Sloane 1986). 
The results suggest that the Danish Superligaen is perceived to be relatively less exciting as the level of PCB is on average 6.62 (compared to 7.75 for the Dutch Eredivisie and 8.11 for the German Bundesliga) and the Danish Fans are on average willing to pay around $€ 5.12$ (compared to $€ 3.24$ in the Netherlands and $€ 3.15$ in Germany) per stadium ticket per game to increase the current level of excitement (see Figure 1). ${ }^{3}$ For reasons of comparison, in addition to the PCB measures as described before, we analyzed the level of OCB based on two different measures. Interestingly, both, the $\mathrm{H}$-Index of $\mathrm{CB}$ and the Competitive Balance Ratio $(\mathrm{CBR})^{4}$, indicate the Dutch Superligaen to be comparably less balanced. Moreover, for a long time the Danish Superligaen was the (relatively) most balanced league though the decrease of OCB in Denmark was quite dramatic during the recent years (see Figure 2).

These results suggest that a difference between OCB and PCB exists. In the next section we attempt to take a look behind this insight and explore potential theories that may serve to explain these differences between OCB and PCB.

\section{Possible Theoretical Reasons for Differences between OCB and PCB}

If fans would follow the model of the perfectly-rational homo oeconomicus, then there should be no difference between the statistically measured CB in European football leagues and the perceived CB in the eyes of the fans. However, to better understand possible effects of perception that deviate from statistically measured effects, we need to move away from simplistic notions of perfect information, perfectly rational behaviour and textbook-level microeconomics.

Economic research during the past five decades has contributed to enrich our understanding of economic behaviour by introducing branches like behavioural economics, institutional economics and experimental economics into the mainstream of economic thinking. Altogether they picture an empirically well-supported image of the rational-behaving economic subject that includes imperfect information, subjective and constructive perception as well as rule-following, heuristic behaviour. Cognitive resources are scarce and, consequently, individuals economize on these resources, which includes limiting information gathering (Simon 1955; Stigler 1961), economizing on the interpretative force of the brain by relying on mental models (Kahneman \& Tversky 1979; Denzau \& North 1994; Kahneman 2003a, 2003b) as well as focusing their scarce cognitive resources on those problems where their employment promises to yield extraordinary revenues and reverting to heuristics-following behaviour in ordinary situations (Budzinski 2003; Vanberg 2004).

3 Further analysis reveals that PCB actually matters for fans as their consumption patterns might be affected (Pawlowski 2013a; 2013b; Pawlowski \& Budzinski 2013).

4 The $\mathrm{H}$-Index of $\mathrm{CB}$ is based on the sum of the quadratic share of points won by each club in a league adjusted for the number of teams (Depken 1999). The CBR is derived as the ratio of the average standard deviation of team points to the average SD of league points (Humphreys 2002). 
This is a world where perception matters and plays a considerable role. Rational behaviour, then, does not so much describe 'right' behaviour in terms of statistical facts, but instead - less ambitiously - the consistency of mind and action. Drawing broadly on a body of economic thought that is enriched by these influences, three possible explanations for the (non-)divergence of OCB and PCB can be derived: framing effects (3.1), threshold effects (3.2), and attention level effects (3.3). These effects are discussed in the following.

\subsection{Framing Effects}

Framing effects imply that the context of a perception or a decision situation matters for interpretation and action: individuals are framed by past experiences as well as the environment of a situation and this influences how they perceive and interpret a given phenomenon. With respect to $C B$ this means that fans are not influenced by $a$ given CB-value in an isolated way. Instead, that CB-value is perceived in the context of the previous $C B$-values, which represent the framing of the fans and act as reference points for the individual, subjective valuation. As a consequence, changes in CBvalues become more important than cardinal levels. If $C B$ has been very low in a given league, then any improvement from that low level may be perceived as "high" CB because fans have been accustomed to low CB-levels and take the past imbalance as a reference point (anchoring effects). On the other hand, if CB-levels are high, a small deterioration of CB may already be perceived as "low" CB because fans have adjusted their reference point to the high level. The subjective assessment of $C B$ is then driven by a mismatch of $C B$-expectation and actual $C B$ : if $C B$ is higher than expected, $P C B$ will likely exceed $O C B$, whereas it will fall short of $O C B$ if $C B$ is lower than expected. ${ }^{5}$

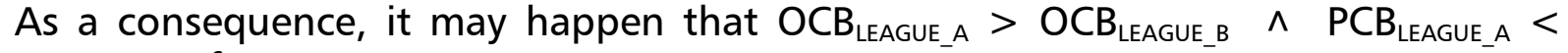
PCB LEAGUE_B ${ }^{6}{ }^{6}$

Consider the following hypothetical example: country $A$, on the one hand, has a comparably imbalanced premier-level league say with CBR-levels oscillating around values of 0.3 . Country B's fans, on the other hand, enjoy a premier-level league with CBR-levels around values of 0.7. Now, in the recent seasons, CBR of League $A$ unexpectedly jumps to 0.45 whereas CBR level of League $B$ unexpectedly drops to 0.55 . While League $B$ remains the more balanced one in OCB terms, framing effects may well drive PCB of (disappointed) League B-fans below the PCB of (positively surprised) League A-fans.

Indeed, in our study, we can find some support for this line of explanation (Pawlowski \& Budzinski 2013). As can be seen in section 2, the decrease in OCB seems to

5 Next to past expressions of $C B$, expectations can additionally be driven by other influences. For instance, CB-expectation could be extraordinary high because of welcomed rule changes or an extraordinary influx of prominent (star) players (allocated to many teams), etc.

6 Coates, Humphreys \& Zhou (2014) employ a somewhat similar thought on a match level when they model individual consumer choice as depending on a utility function that, inter alia, includes the difference between the actual match outcome and the expected match outcome as a (positive or negative) utility source (surprise win by the supported team and surprise loss by the supported team respectively). 
influence perceptions in a stronger way than the level of OCB in the case of the Danish league. Note that the Danish league actually is characterized by a better OCBvalue than the premier-level leagues in the Netherlands and in Germany in the first two periods and still better than the Dutch league in the third period (see figure 2). Yet, the decrease of CB is much more dramatic in Denmark than in the other two leagues. CBR for Denmark has decreased by around 34 per cent (from 0.8 to 0.53 ) from the first to third period, whereas for Germany it has decreased 'only' by around 12 per cent (from 0.66 to 0.58 ) and the Dutch one increased by around 14 per cent (from 0.36 to 0.42 ). So, generalizing over the three periods, we can - a bit simplifying - see that while for $O C B$ levels $O C B_{\text {Denmark }}>0 \mathrm{OCB}_{\text {Germany }}>0 \mathrm{OCB}_{\text {Netherlands }}$ holds, $\mathrm{PCB}$-levels are characterized by $\mathrm{PCB}_{\text {Denmark }}<\mathrm{PCB}_{\text {Netherlands }}<\mathrm{PCB}_{\text {Germany. }}$.

Thus, the difference between OCB- and PCB-levels may be explained by changes of $\mathrm{CB}$ (as a framing factor) being a stronger influence on fans' perception than $\mathrm{CB}$-levels.

\subsection{Threshold Effects}

Threshold effects correspond to an important behavioural economics-qualification of the concept of optimality: instead of aspiring to an optimal level of satisfaction in regard to the consumption of any goods, individuals are typically less ambitious and settle for a "satisficing" level. Once a certain level of satisfaction is reached, no more further cognitive resources are spent on further optimizing the consumption in question. Instead, the scarce cognitive resources are focused on consumption areas where no satisfying level has yet been reached. In other words, (small) variations above the satisficing level do not matter. However, if the "satisficing" threshold is undercut, then a strong (demand) reaction is triggered (discontinuity effect).

While the empirical evidence for such effects differs among different types of wants and needs as well as among corresponding goods categories, fans' desideratum for balanced competition within the league may provide a fitting example. So far, sports economics research has struggled to identify any optimal level of $C B$; identification of optimum has neither theoretically, nor empirically been managed. It appears to be broadly accepted that this, inter alia, has to do with conflicting influences such as the attractiveness of close competition in terms of high uncertainty of outcome and unpredictability of results versus the attractiveness of superstar players and superstar teams that inevitably generate some minimum imbalance. Perfect CB would basically imply a random walk (without any favourites or underdogs) and most sports economists will agree that this is not optimal. An additional factor in question may well be that fans are not interested in any optimal $C B$, i.e. they do not have an (explicit or implicit) notion of an optimum regarding $C B$ themselves. Instead, fans may rather be interested in a satisficing $C B$. In this case, a discontinuity effect emerges: $C B$ changes above the satisficing level of $C B$ are not perceived to be relevant for consumption behaviour whereas a drop of CB below the satisficing level may cause discontinuous, perhaps even extreme consumption reactions.

Again, we find preliminary supportive evidence that the relation between $C B$ and fans' consumption includes a discontinuity in terms of some kind of a "tipping point" 
or threshold above which changes in CB are not very relevant for fans whereas fans' consumption behavior does change significantly once $C B$ falls below that crucial threshold: while Pawlowski (2013a; 2013b) could detect that the PCB conditional demand curves are s-shaped (indicating an area of inelastic response for both, very high and very low values of PCB), the findings by Pawlowski and Budzinski (2013) suggest that changes in the fans' willingness-to-pay for improvements of $C B$ are triggered by CB falling below a crucial threshold, i.e. WTP 'jumps' to a higher level as a reaction to this.

\subsection{Attention Level Effects}

In addition to the theoretical effects and their preliminary supportive evidence discussed above, a third effect might be relevant in this context as valuations of individuals depend on the degree of (their) attention that is drawn to a specific phenomenon. This attention level depends - next to the individual's preferences - on saliencerelated aspects like media intensity (presence in broadcasting, newspapers, internet, boulevard media, etc.) and relative importance of specific subparts of the overall phenomenon. In regard to the valuation of goods, a typical consequence is that valuations of those products that receive high attention levels outshine those of products with low attention levels in the perception of the consumer.

With respect to the competitive balance of premier-level football leagues, the effects of diverging attention levels may be particularly relevant since the relative importance of competition among teams differs significantly depending on the positions within the league's ranking that these teams are fighting for. Put drastically, competition for top positions is considerably more important than competition in the 'dull' midfield: while the close duel of two teams for championship fame will be associated with high attention levels, a close fight of three teams for position 10 in an 18- or 20-teams league will certainly receive significantly lower attention levels. The relative importance of the championship race is obviously higher than of the race for a midfield position ${ }^{7}$ and, correspondingly, media intensity (regarding all dimensions) will be much higher for the former than for the latter.

However, the diverging attention levels can have an important influence on the perception of the competitive balance of the league. Consider the following two scenarios for an 18-teams league: A) the championship race between three teams is close until the last minute of the season; the three top teams are very evenly matched in terms of performance levels. However, the "race for position 10" is early decided because the differences in competitiveness are rather high among the midfield

Please note, that competition for midfield positions is relevant in some leagues (e.g. the German Bundesliga) because media revenues are (partly) redistributed based on the past season(s) positioning in the final league table(s). Therefore, different (midfield) positions go along with (slightly) different amounts of club-specific media revenues. However, without any doubt, competition for the top positions is considerably more important for (most of the) fans. Recent sports economics research provides evidence that the same is true for the participants of the league: effort levels for comparably less important midfield position races are lower than such for more important decisions like the race for the championship (Feddersen, Humphreys \& Soebbing 2012). 
teams; B) The championship race is decided very early in the season due to the clear dominance of one team that is head and toes above the competition. However, the "race for position 10" is very intense among four teams that are very evenly matched. It should not be surprising if the PCB of scenario A is significantly and considerably higher than the PCB of scenario B. However, the standard OCB measures, measuring the $C B$ of the overall league, will not necessarily come to the same result because they do not distinguish between a close fight for position 1 and a close "fight for position 10". So, while statistically (OCB) every sub-competition within the league is associated with the same value, the fans $(P C B)$ will value some sub-competitions higher than others - due to diverging attention levels. Differences between OCB and PCB may be rooted in the phenomenon that CB between (few) top teams may be more important for fan perception than the balance of the league in total.

Looking into typical European soccer premier-level leagues, we can indentify several sub-competitions that exceed the 'ordinary' fight for positions in the league ranking in terms of relative importance and media intensity, i.e. the championship race, the race for the qualification positions for the European-level competitions (UEFA Champions League; UEFA Europe League), the race against relegation ${ }^{8}$, and qualification positions for play-off rounds (depending on the league's championship structure).

The consequent hypothesis is that PCB is more driven by the closeness of these comparatively important sub-competitions (i.e. by the $C B$ among the contenders for the relevant positions in the league ranking) than by the $C B$ of the overall league that typically determines the standard OCB measures. If this hypothesis can be supported, then the gap between PCB and OCB will disappear when OCB measures are employed that do not target the league as a whole but focus on the relevant sub-competitions (i.e. mid-term components of league competition). The next section provides some supportive evidence for this hypothesis.

\section{Competitive Balance and Attention Level Effects: Preliminary Evidence}

Jennett (1984) was the first who introduced the idea to measure the so-called midterm components of UO who disentangle the overall CB measure by looking at match significance. His and other modified measures were employed in subsequent studies to test the relevance of mid-term UO for consumers objectively. The findings suggest a significant positive effect on stadium attendance if a team still had a chance to contend for the championship (Jennett 1984; Pawlowski \& Anders 2012) or to earn promotion (Forrest \& Simmons 2002). Therefore, - and in contrast to the ambiguous findings with regard to the relevance of objectively measured short- and long-term UO - objectively measured mid-term UO seems to be of importance for fan behavior. Thus, it appears promising to look at whether OCB and PCB differ in this dimension.

8 European football leagues are typically open leagues in which the teams on the last positions in the ranking are relegated to a lower-level league and replaced by the top performers of these power level leagues. 
In addition to the overall index of PCB generated by the instrument as described in chapter 2, 11 items reflecting the short-, mid- and long-term UO were evaluated within the project on a 4 -point scale $(1 \equiv$ I do not agree ... 4 II agree completely) with the following type of question:

Thinking back to previous seasons, what is your opinion of the LEAGUE with regard to...?.

Figure 3 summarizes the mean values for the 4 items reflecting mid-term UO. Interestingly, in line with the findings for the overall index of PCB, the Danish Superligaen is perceived to be significantly less balanced also with regard to the mid-term UO. Specifically, the race for the championship appears to be less balanced as most of the Danish Fans disagree with the statement that the fight for the title remains exciting for a long time within a season.

These perceptions by the fans are confirmed by the available 'objective' data. Five years prior to the inquires (season 2006/07-2010/11) there have been four different champions in the German Bundesliga and the Dutch Eredivisie each while FC Copenhagen won all but one championship in Denmark. Furthermore, the "championship relevance" of games further strengthens this result. A game possesses championship relevance if at least one of two teams still has a (mathematical) chance of winning the championship. Significantly, in the season before the inquiry took place $(2010 / 11)$ only $45 \%$ of the games in Denmark had such championship relevance while it was more than $60 \%$ of the games in Germany and the Netherlands.

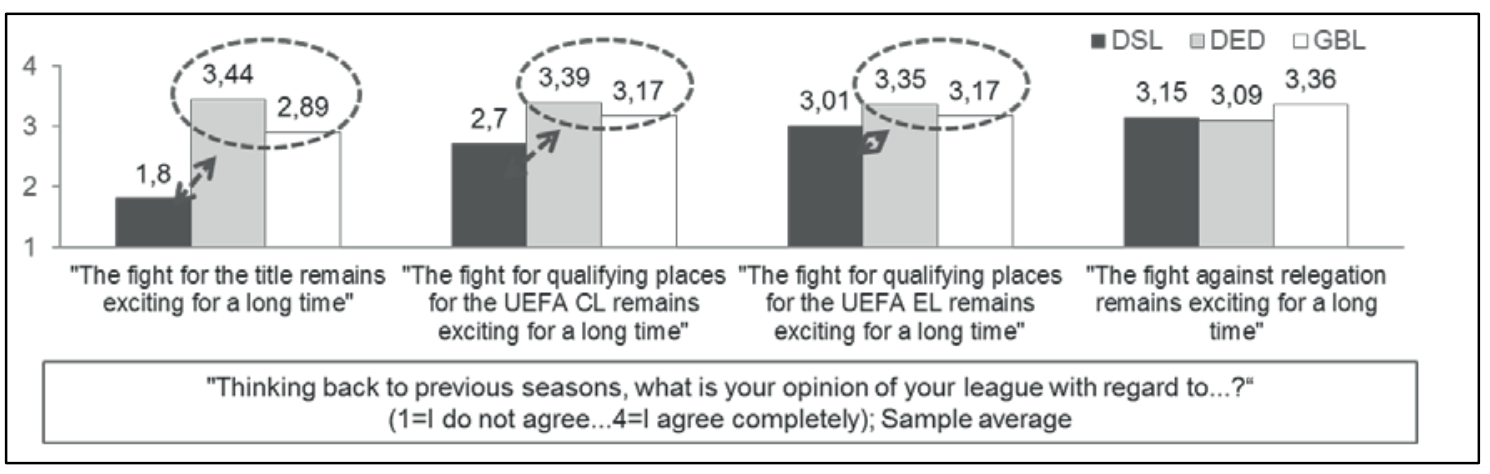

Figure 3: Fans' evaluation of different dimensions of excitement in the Danish Superligaen (DSL), the Dutch Eredivisie (DED) and the German Bundesliga (GBL) (Pawlowski 2013a).

Figure 4 provides some descriptive evidence based on the average winning margin in three different leagues. While the champions in the Dutch Eredivisie and the German Bundesliga are on average 3.4 and respectively 5.2 points ahead, the champions in the Danish Superligaen are on average 12.4 points ahead of the team in second place. Significantly, in 2010/11 FC Copenhagen was 26 points ahead of the runnerup Odense BK. 


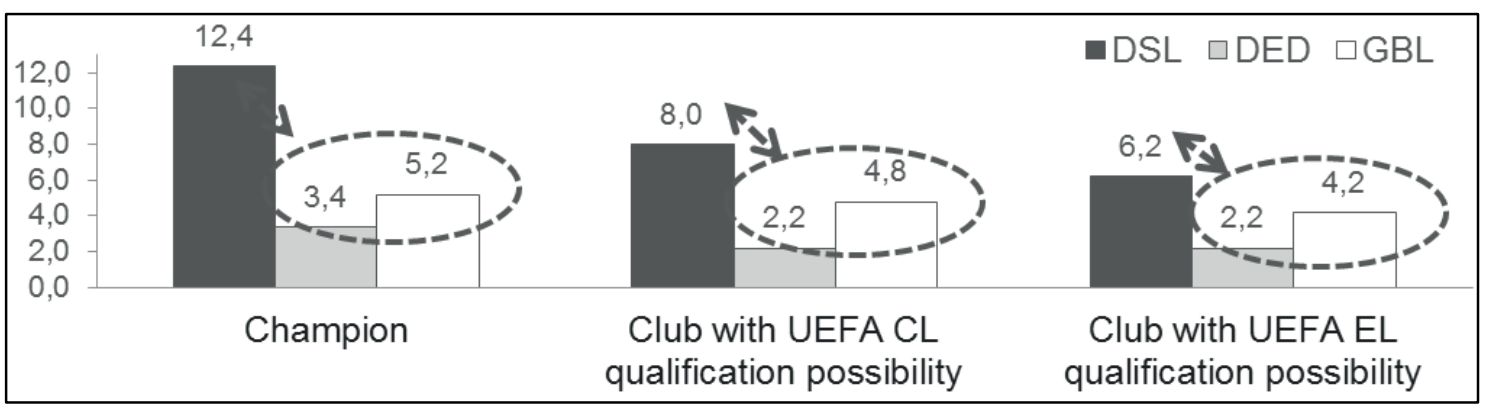

Figure 4: Average number of points ahead in the Danish Superligaen, the Dutch Eredivisie and the German Bundesliga.

In summary, the stronger imbalance of the Danish league can be found both in perceived and objective measures if mid-term measures are analyzed. For instance, midterm PCB and mid-term OCB measures both reflect the comparatively strong imbalance of the Danish league when it comes to analysing championship relevance. While the ranking among the Dutch and the German league, which are rather close to each other, is not unambiguous, still the objective and subjective measures show exactly the same pattern, i.e. $\mathrm{OCB}_{\text {Denmark }}<\mathrm{OCB} \mathrm{B}_{\text {Germany, Netherlands }}$ and $\mathrm{PCB}_{\text {Denmark }}<\mathrm{PCB}_{\text {Germany, Nether- }}$ lands. This supports our hypothesis that PCB is more driven by the closeness of comparatively important sub-competitions (i.e. by the $C B$ among the contenders for the relevant positions in the league ranking) than by the $C B$ of the overall league: the imbalance of the championship race in Denmark dominates the balance of the overall league in regard to the assessment and behaviour of the fans.

\section{Summary and Conclusion}

In this chapter we try to better understand possible reasons for the gap between OCB and PCB as previously observed by Pawlowski (2013a; 2013b) as well as Pawlowski \& Budzinski (2013). First, we recapitulate the findings of our previous studies and explain some observations by introducing and applying behavioural economic concepts. Based on these considerations, framing effects and threshold effects seem to occur which might be reasons for some divergences between OCB and PCB. Second, we provide preliminary evidence that suggests that the gap between $P C B$ and OCB disappears when measures are employed that do not target the league as a whole but focus on relevant sub-competitions. Therefore, attention level effects seem to occur in this context as well: (for instance) a balanced championship race is more important to the fans than a high overall balance in the league.

There are two lines of important conclusions from this insight. Firstly, sports economics research into $C B$ needs to focus on thoroughly analyzing mid-term $U O$ in the future. Although Szymanski (2006) already mentioned some years ago that there "have been surprisingly few other papers that have examined empirically the effect of championship uncertainty", the mid-term dimension of CB has been rather neglected so far (in comparison to overall CB-analysis). Therefore, further research is necessary in order to develop and employ mid-term UO-measures along both of the lines that Fort and Maxcy (2003) emphasize, i.e. the analysis of competitive balance 
(ACB) (Pawlowski \& Bloching 2013) and the analysis of uncertainty of outcome (UOH). Secondly, our analysis entails valuable implications for the management and governance of leagues: in order to make a league more attractive for fans, it is not so much relevant to improve overall OCB (i.e. the average CB of the league). Instead, it is more effective to ensure close competitions for outstanding position in the league ranking that receive high attention levels by the fans like the championship race, the fight against relegation or other relevant sub-competitions. In order to operationalize the management and policy implications, however, more research along the lines of our first conclusion is necessary, including research on the relative importance of different sub-competitions for the perception of the fans.

\section{References}

Benz, M.-A., Brandes, L. \& Franck, E. (2009): Do Soccer Associations Really Spend on a Good Thing? Empirical Evidence on Heterogeneity in the Consumer Response to Match Uncertainty of Outcome, in: Contemporary Economic Policy, Vol. 27, 2, pp. 216-235.

Budzinski, O. (2003): Cognitive Rules, Institutions, and Competition, in: Constitutional Political Economy, Vol. 14, 3, pp. 215-235.

Buraimo, B. \& Simmons, R. (2008): Do Sports Fans Really Value Uncertainty of Outcome? Evidence from the English Premier League, in: International Journal of Sport Finance, Vol. 3, 3, pp. 146-155.

Cairns, J. P., Jennett, N. \& Sloane, P. (1986): The Economics of Professional Team Sports: A Survey of Theory and Evidence, in: Journal of Economic Studies, Vol. 13, 1, pp. 3-80.

Coates, D. \& Humphreys, B. R. (2010): Week to Week Attendance and Competitive Balance in the National Football League, in: International Journal of Sport Finance, Vol. 5, 4, pp. 239-252.

Coates, D., Humphreys, B. R. \& Zhou, L. (2014): Outcome Uncertainty, ReferenceDependent Preferences and Live Game Attendance, in: Economic Inquiry (forthcoming).

Denzau, A. T. \& North, D. C. (1994): Shared Mental Models - Ideologies and Institutions, in: Kyklos, Vol. 47, 1, pp. 3-31.

Depken, C. A. (1999): Free Agency and the Competitiveness of MLB, in: Review of Industrial Organization, Vol. 14, 3, pp. 205-217.

Feddersen, A., Humphreys, B. R. \& Soebbing, B. P. (2012): Contest Incentives in European Football, Working Ppaer No. 2012-13, University of Alberta. 
Flores, R., Forrest, D. \& Tena, J. D. (2010): Impact on Competitive Balance from Allowing Foreign Players in a Sports League: Evidence from European Soccer, in: Kyklos, 63, pp. 546-557.

Forrest, D. \& Simmons, R. (2002): Outcome Uncertainty and Attendance Demand: The Case of English Soccer, in: Journal of the Royal Statistical Society, Series D (The Statistician), Vol. 51, pp. 229-241.

Forrest, D., Beaumont, J., Goddard, J. \& Simmons, R. (2005): Home Advantage and the Debate about Competitive Balance in Professional Sports Leagues, in: Journal of Sports Sciences, Vol. 23, pp. 439-445.

Fort, R. \& Maxcy, J. (2003): Competitive Balance in Sports Leagues: An Introduction, in: Journal of Sports Economics, Vol. 4, 2, pp. 154-160.

Humphreys, B. R. (2002): Alternative Measures of Competitive Balance in Sports Leagues, in: Journal of Sports Economics, Vol. 3, 2, pp. 133-148.

Jennett, N. (1984): Attendances, Uncertainty of Outcome and Policy in Scottish League Football, in: Scottish Journal of Political Economy, Vol. 31, pp. 176-198.

Kahneman, D. (2003a): A Psychological Perspective on Economics, in: The American Economic Review, Vol. 93, 2, pp. 162-168.

Kahneman, D. (2003b): Maps of Bounded Rationality: Psychology for Behavioral Economics, in: The American Economic Review, Vol. 93, 5, pp. 1449-1475.

Kahneman, D. \& Tversky, A. (1979): Prospect Theory: An Analysis of Decision under Risk, in: Econometrica, Vol. 47, 2, pp. 263-292.

Pawlowski, T. (2013a): Wettbewerbsintensität im Profifußball - Eine empirische Untersuchung zur Bedeutung für die Zuschauer, Wiesbaden: Springer-Gabler.

Pawlowski, T. (2013b): Testing the Uncertainty of Outcome Hypothesis in European Professional Football: A Stated Preference Approach, in: Journal of Sports Economics, Vol. 14, 4, pp. 341-367.

Pawlowski, T. \& Anders, C. (2012): Stadium Attendance in German Professional Football: The (Un)Importance of Uncertainty of Outcome Reconsidered, in: Applied Economics Letters, Vol. 19, pp. 1553-1556.

Pawlowski, T. \& Bloching, B. (2013): How Exciting are the Major European Football Leagues? Main findings of a Study on the Competitive Balance within Football Leagues, http://www.rolandberger.com/media/pdf/Roland_Berger_Competitive_Balance_of_Football_Leagues_20130220.pdf (accessed 2013-12-02). 
Pawlowski, T. \& Budzinski, O. (2013): The (Monetary) Value of Competitive Balance for Sport Consumers - A Stated Preference Approach to European Professional Football, in: International Journal of Sport Finance, Vol. 8, 2, pp. 112-123.

Pawlowski, T., Breuer, C. \& Hovemann, A. (2010): Top Clubs' Performance and the Competitive Situation in European Domestic Football Competitions, in: Journal of Sports Economics, Vol. 11, pp. 186-202.

Rottenberg, S. (1956): The Baseball Player's Labour Market, in: Journal of Political Economy, Vol. 64, 3, pp. 242-258.

Simon, H. A. (1955): A Behavioral Model of Rational Choice, in: The Quarterly Journal of Economics, Vol. 69, 1, pp. 99-118.

Stigler, G. J. (1961): The Economics of Information, in: Journal of Political Economy, Vol. 69, pp. 213-225.

Szymanski, S. (2006): Uncertainty of Outcome, Competitive Balance and the Theory of Team Sports, in: Andreff, W. \& Szymanski, S. (eds.), Handbook on the Economics of Sport, Cheltenham: Elgar: pp. 597-600.

Theil, H. (1967): Economics and Information Theory, Amsterdam: North-Holland. Vanberg, V. J. (2004): The Rationality Postulate in Economics: Its Ambiguity, Its Deficiency and Its Evolutionary Alternative, in: Journal of Economic Methodology, Vol. 11,1 , pp. 1-29.

Zimbalist, A. S. (2002): Competitive Balance in Sports Leagues: An Introduction, in: Journal of Sports Economics, Vol. 3, 2, pp. 111-121.

*** This paper will be published in:

Contemporary Research in Sports Economics - Proceedings of the $5^{\text {th }}$ ESEA Conference

Oliver Budzinski \& Arne Feddersen (eds.)

Frankfurt a.M.: Lang International Publishers 2014

\section{Prolog}

1. Introduction (Oliver Budzinski \& Arne Feddersen)

Financial Fair Play in European Football

2. Financial Fair Play: Winners and Losers on and off the Pitch (Thomas Peeters \& Stefan Szymanski) 
3. Financial Fair Play - Why Loss-Making Is a Problem: The Example of the English Football League (Sean Hamil)

4. The American View on Financial Fair Play (Joel Maxcy)

5. The Competition Economics of Financial Fair Play (Oliver Budzinski)

6. Socio-economic Doping and Enhancement in Sport: A Case-based Analysis of Dynamics and Structural Similarities (Thomas Könecke \& Mathias Schubert)

Performance and Competition in International Football

7. In Urgent Need of Change? Within-season Coach Dismissals, Regression-to-themean, and Performance of Football Teams (Nikolaus Beck \& Mark Meyer)

8. Competitive Balance and Attention Level Effects: Theoretical Considerations and Preliminary Evidence (Tim Pawlowski \& Oliver Budzinski)

9. Spill-overs? Economic Progress, Football Facilities and the 2011 Asia Cup (Peter Ochieng)

New Research on Individual Sports

10. Analysis of Event Visitors' Expenditure Patterns: The Case of the Three FIS Ski Jumping World Cup Events 2013 (Grzegorz Kwiatkowski \& Ove Oklevik)

11. Public Opinion on Doping in Cycling: Differences among Population Groups (Daam van Reeth \& Wim Lagae)

12. The Economics of Motorsport Centers (Anika Müller \& Oliver Budzinski)

The Economics of Sports Events

13. The Winner's Curse in Sports Economics (Wladimir Andreff)

14. Sports on the Air: A GARCH Examination of the Impact of Broadcasts of Live Sporting Events on Television Audience Sizes (José Baños, Levi Pérez, Victor Puente \& Plácido Rodríguez)

15. Gridiron Games: A Case Analysis of Turf War Issues and the Economic, Social, Cultural, and Political Incentives for Government Subsidization (Christopher $M$. Keshock, Brooke Forester \& Shelley Holden)

\section{Epilogue}

16. A Survey of Five Years of ESEA Conferences (Daam van Reeth) 


\section{Diskussionspapiere aus dem Institut für Volkswirtschaftslehre der Technischen Universität IImenau}

Nr. 30 Steinrücken, Torsten: Die Legitimation staatlicher Aktivität durch vertragstheoretische Argumente: Anmerkungen zur Kritik an der Theorie des Gesellschaftsvertrages, März 2003.

Nr. 31 Steinrücken, Torsten; Jaenichen, Sebastian: Heterogene Standortqualitäten und Signalstrategien: Ansiedlungsprämien, Werbung und kommunale Leuchtturmpolitik, April 2003.

Nr. 32 Steinrücken, Torsten: Funktioniert ,fairer' Handel? Ökonomische Überlegungen zum alternativen Handel mit Kaffee, Juli 2003.

Nr. 33 Steinrücken, Torsten; Jaenichen, Sebastian: Die Wiederentdeckung der Zweitwohnsitzsteuer durch die Kommunen - zu Wirkungen und Legitimation aus ökonomischer Sicht, September 2003.

Nr. 34 Rissiek, Jörg; Kressel, Joachim: New Purchasing \& Supply Chain Strategies in the Maintenance, Repair and Overhaul Industry for Commercial Aircraft, September 2003.

Nr. 35 Steinrücken, Torsten; Jaenichen, Sebastian: Europäische Beihilfekontrolle und Public Utilities - Eine Analyse am Beispiel öffentlicher Vorleistungen für den Luftverkehr, Dezember 2003.

Nr. 36 Voigt, Eva; GET UP: Gründungsbereitschaft und Gründungsqualifizierung - Ergebnisse der Studentenbefragung an der TU Ilmenau, April 2004.

Nr. 37 Steinrücken, Torsten; Jaenichen, Sebastian: Levelling the playing field durch staatliche Beihilfen bei differierender Unternehmensmobilität, Mai 2004.

Nr. 38 Steinrücken, Torsten; Jaenichen, Sebastian: Sekundärwirkungen von Unternehmensansiedlungen - Eine Beurteilung staatlicher Aktivität beim Auftreten paretorelevanter Nettoexternalitäten, Juni 2004.

Nr. 39 Kallfaß, Hermann H.: Wettbewerb auf Märkten für Krankenhausdienstleistungen - eine kritische Bestandsaufnahme, Juni 2004.

Nr. 40 Engelmann, Sabine: Internationale Transfers und wohlfahrtsminderndes Wachstum, September 2004.

Nr. 41 Steinrücken, Torsten; Jaenichen, Sebastian: Zum Einfluss von Ausländern auf die Wirtschaftsleistung von Standorten - Ist Zuwanderung ein Weg aus der ostdeutschen Lethargie?, Oktober 2004. 
Nr. 42 Steinrücken, Torsten; Jaenichen, Sebastian: Wer ist wirklich reich? - Zu Problemen der Wohlfahrtsmessung durch das Bruttoinlandsprodukt, April 2005.

Nr. 43 Steinrücken, Torsten; Jaenichen, Sebastian: Wo bleiben die Subventionssteuern? - Probleme des Beihilfenrechts und ein alternatives Regulierungskonzept, Mai 2005.

Nr. 44 Jaenichen, Sebastian; Steinrücken, Torsten; Schneider, Lutz: Zu den ökonomischen Wirkungen gesetzlicher Feiertage - Eine Diskussion unter besonderer Berücksichtigung der Arbeitszeitpolitik, Juni 2005.

Nr. 45 Kuchinke, Björn A.: Qualitätswettbewerb zwischen deutschen Akutkrankenhäusern unter besonderer Berücksichtigung von DRG und Budgets, Juni 2005.

Nr. 46 Kuchinke, Björn A.; Walterscheid, Heike: Wo steht der Osten? Eine ökonomische Analyse anhand von Wohlfahrts- und Happinessindikatoren, Juni 2005.

Nr. 47 Kuchinke, Björn A.; Schubert, Jens M.: Staatliche Zahlungen an Krankenhäuser: Eine juristische und ökonomische Einschätzung nach Altmark Trans und der Entscheidung der Kommission vom 13.7.2005, August 2005.

Nr. 48 Steinrücken, Torsten; Jaenichen, Sebastian: Überkapazitäten zur Absicherung politischer Risiken und Instrumente finanzwirtschaftlicher Gegensteuerung, November 2005.

Nr.49 Jaenichen, Sebastian; Steinrücken, Torsten: Opel, Thüringen und das Kaspische Meer, Januar 2006.

Nr. 50 Kallfaß, Hermann H.: Räumlicher Wettbewerb zwischen Allgemeinen Krankenhäusern, Februar 2006.

Nr. 51 Sickmann, Jörn: Airport Slot Allocation, März 2006.

Nr. 52 Kallfaß, Hermann H.; Kuchinke, Björn A.: Die räumliche Marktabgrenzung bei Zusammenschlüssen von Krankenhäusern in den USA und in Deutschland: Eine wettbewerbsökonomische Analyse, April 2006.

Nr. 53 Bamberger, Eva; Bielig, Andreas: Mehr Beschäftigung mittels weniger Kündigungsschutz? Ökonomische Analyse der Vereinbarungen des Koalitionsvertrages vom 11. 11. 2005, Juni 2006.

Nr. 54 Jaenichen, Sebastian; Steinrücken, Torsten: Zur Ökonomik von Steuergeschenken - Der Zeitverlauf als Erklärungsansatz für die effektive steuerliche Belastung, Dezember 2006. 
Nr. 55 Jaenichen, Sebastian; Steinrücken, Torsten: Wirkt eine Preisregulierung nur auf den Preis? Anmerkungen zu den Wirkungen einer Preisregulierung auf das Werbevolumen, Mai 2007.

Nr. 56 Kuchinke, B. A.; Sauerland, D.; Wübker, A.: Determinanten der Wartezeit auf einen Behandlungstermin in deutschen Krankenhäusern - Ergebnisse einer Auswertung neuer Daten, Februar 2008.

Nr. 57 Wegehenkel, Lothar; Walterscheid, Heike: Rechtsstruktur und Evolution von Wirtschaftssystemen - Pfadabhängigkeit in Richtung Zentralisierung?, Februar 2008.

Nr. 58 Steinrücken, Torsten; Jaenichen, Sebastian: Regulierung und Wohlfahrt in einem Modell mit zwei Aktionsparametern, März 2008.

Nr. 59 Lehnert, Ninja M.: Externe Kosten des Luftverkehrs - Ein Überblick über den aktuellen Stand der Diskussion, April 2008.

Nr. 60 Walterscheid, Heike: Reformbedarf etablierter Demokratien im Kontext dezentralisierter Gesellschaftssysteme - Grundlegende Hindernisse bei Steuersystemreformen", April 2010.

Nr. 61 Walterscheid, Heike; Wegehenkel, Lothar: Kostenstruktur, Zahlungsbereitschaft und das Angebot von Mediengütern auf Medienmärkten, Juni 2008.

Nr. 62 Walterscheid, Heike; Wegehenkel, Lothar: Wohlstand der Nationen und handlungsrechtliche Struktur eines Gesellschaftssystems, September 2008.

Nr. 63 Dewenter, Ralf; Haucap, Justus; Wenzel, Tobias: Indirect Network Effects with Two Salop Circles: The Example oft the Music Industry, Juni 2009.

Nr. 64 Dewenter, Ralf; Jaschinski, Thomas; Wiese, Nadine: Wettbewerbliche Auswirkungen eines nichtneutralen Internets, Juli 2009.

Nr. 65 Dewenter, Ralf; Haucap, Justus; Kuchinke, Björn A.: Das Glück und Unglück von Studierenden aus Ost- und Westdeutschland: Ergebnisse einer Befragung in Ilmenau, Bochum und Hamburg, Oktober 2009.

Nr. 66 Kuchinke, Björn A.; Zerth, Jürgen; Wiese, Nadine: Spatial Competition between Health Care Providers: Effects of Standardization, Oktober 2009.

Nr. 67 Itzenplitz, Anja; Seifferth-Schmidt, Nicole: Warum Klimakonferenzen scheitern, aber dennoch zum Wohl des Weltklimas kooperiert wird, Juli 2010. 
Nr. 68 Kallfaß, Hermann H.: Die Aufmerksamkeit für, die Nutzung der und die Werbung in Medien in Deutschland, November 2010.

Nr. 69 Budzinski, Oliver: Empirische Ex-Post Evaluation von wettbewerbspolitischen Entscheidungen: Methodische Anmerkungen, Januar 2012.

Nr. 70 Budzinski, Oliver: The Institutional Framework for Doing Sports Business: Principles of EU Competition Policy in Sports Markets, January 2012.

Nr. 71 Budzinski, Oliver; Monostori, Katalin: Intellectual Property Rights and the WTO, April 2012.

Nr. 72 Budzinski, Oliver: International Antitrust Institutions, Juli 2012.

Nr. 73 Lindstädt, Nadine; Budzinski, Oliver: Newspaper vs. Online Advertising - Is There a Niche for Newspapers in Modern Advertising Markets?

Nr. 74 Budzinski, Oliver; Lindstädt, Nadine: Newspaper and Internet Display Advertising - Co-Existence or Substitution?, Juli 2012b.

Nr. 75 Budzinski, Oliver: Impact Evaluation of Merger Control Decisions, August 2012.

Nr. 76 Budzinski, Oliver; Kuchinke, Björn A.: Deal or No Deal? Consensual Arrangements as an Instrument of European Competition Policy, August 2012.

Nr. 77 Pawlowski, Tim, Budzinski, Oliver: The (Monetary) Value of Competitive Balance for Sport Consumers, Oktober 2012.

Nr. 78 Budzinski, Oliver: Würde eine unabhängige europäische Wettbewerbsbehörde eine bessere Wettbewerbspolitik machen?, November 2012.

Nr. 79 Budzinski, Oliver; Monostori, Katalin; Pannicke, Julia: Der Schutz geistiger Eigentumsrechte in der Welthandelsorganisation - Urheberrechte im TRIPS Abkommen und die digitale Herausforderung, November 2012.

Nr. 80 Beigi, Maryam H. A.; Budzinski, Oliver: On the Use of Event Studies to Evaluate Economic Policy Decisions: A Note of Caution, Dezember 2012.

Nr. 81 Budzinski, Oliver; Beigi, Maryam H. A.: Competition Policy Agendas for Industrializing Countries, Mai 2013.

Nr. 82 Budzinski, Oliver; Müller, Anika: Finanzregulierung und internationale Wettbewerbsfähigkeit: der Fall Deutsche Bundesliga, Mai 2013.

Nr. 83 Dosse, Anna Maria: Methods for Calculating Cartel Damages: A Survey, Dezember 2013. 